\title{
MICRONUCLEI: A PROGNOSTIC TOOL
}

Ankit Agarwal ${ }^{1}$, Rinky Ahuja ${ }^{2}$, Manisha Tijare ${ }^{3}$, Sonalika Ghate ${ }^{4}$, Anand Tegginamani ${ }^{5}$, Sanyog Pathak ${ }^{6}$

\section{HOW TO CITE THIS ARTICLE:}

Ankit Agarwal, Rinky Ahuja, Manisha Tijare, Sonalika Ghate, Anand Tegginamani, Sanyog Pathak. "Micronuclei: A Prognostic Tool". Journal of Evolution of Medical and Dental Sciences 2014; Vol. 3, Issue 49, October 02;

Page: $11762-11765$, DOI: $10.14260 /$ jemds/2014/3545

ABSTRACT: Squamous cell carcinoma is one the most common oral mucosal malignant tumor, diagnosis of oral squamous cell carcinoma rarely presents difficulty, it is the cancer staging and histo pathological grading that are more important for prognosis, micronuclei are good prognostic indicator. Micronuclei screening can be done easily by exfoliative cytology, one of the most valuable diagnostic method other than routine histopathology (H and E-stained sections) and immunohistochemistry. It has been used in the detection of oral squamous cell carcinoma and has been shown to have a sensitivity of $94 \%$, specificity of $100 \%$, and an accuracy of $95 \%$. Micronuclei frequencies were also found to be raised with increasing histological grades of squamous cell carcinoma.

KEYWORDS: Micronuclei, Exfoliative cytology, Squamous cell carcinoma.

INTRODUCTION: A micronucleus is the erratic nucleus that is formed during the anaphase of mitosis or meiosis. Micronuclei (the name means 'small nucleus') are cytoplasmic bodies having a portion of acentric chromosome or whole chromosome which was not carried to the opposite poles during the anaphase. Chromosomal damage by carcinogens to dividing basal cells of the epithelium results in the production of micronuclei in the daughter cells which migrate up through the epithelium and are exfoliated.

The micronucleus test on exfoliated cells has been successfully used to: (1) recognize population groups at an elevated risk for cancer of the oral cavity or urinary bladder; (2) estimate synergistic or additive effects of carcinogen exposure (cigarette smokers plus drinkers of alcoholic beverages); (3) pinpoint the site within an organ from which most carcinomas will develop. ${ }^{1}$ Micronuclei are induced in oral exfoliated cells by a variety of substances, including genotoxic agents and carcinogenic compound in tobacco, betel nut, and alcohol.

Tobacco-specific nitrosamines have been reported to be potent clastogenic and mutagenic agents which are thought to be responsible for the induction of chromatid/chromosomal aberrations resulting in production of micronuclei. ${ }^{2}$ The genotoxic and carcinogenic chemicals released from betel nut and tobacco and also the calcium hydroxide content of lime present in the betel quid are thought to be responsible for promotion of reactive oxygen species from areca nut extracts. These reactive oxygen species can in turn cause damage to the DNA. ${ }^{7}$

FORMATION OF MICRONUCLEI: Micronuclei are extra nuclear cytoplasmic bodies. They are induced in cells by numerous genotoxic agents that damage the chromosomes. The damaged chromosomes, in the form of acentric chromatids or chromosome fragments, lag behind in anaphase when centric elements move towards the spindle poles. After telophase, the undamaged chromosomes, as well as the centric fragments, give rise to regular daughter nuclei. 
The lagging elements are included in the daughter cells, too, but a considerable proportion is transformed into one or several secondary nuclei, which are, as a rule, much smaller than the principal nucleus and are therefore called micronuclei. ${ }^{3}$

DISCUSSION: Squamous cell carcinoma of the oral mucosa accounts for $90 \%$ to $95 \%$ of all oral malignancies. ${ }^{3}$ Oral exfoliative cytology has been used extensively for screening cellular alteration in oral squamous cell carcinoma cases. An accuracy of $95 \%$ and a reliability of more than $96 \%$ in detection of squamous cell carcinoma in mass screening have been reported in the literature. ${ }^{4}$ Oral exfoliative cytology can reveal various cellular alterations in squamous cell carcinoma. It includes karyorrhexis, karyolysis, micronucleus formation, pyknosis, binucleation, broken-egg nucleus, anucleation, etc. 5,6

Micronuclei in oral exfoliated cells is a marker of chromosomal damage caused by genotoxic agents from tobacco and tobacco-related substances, alcohol, etc. 7,13 The micronucleus assay has been used to assess the genotoxic damage in oral squamous cell carcinoma and oral premalignancies.8,9 It has been established that genomic damage is produced by genotoxic substances, medical procedures (radiation, chemicals), micronutrient deficiency (folic acid), lifestyle factors (alcohol, smoking, stress, drugs), and genetic factors such as defects in metabolism and/or in repair of DNA. ${ }^{10,11}$

The Micronuclei assay has been reported to correlate well with the histological grading of oral squamous cell carcinoma and leukoplakia. Incidence of micronuclei has been analyzed by various studies in normal patients, oral premalignancies, and oral squamous cell carcinoma. ${ }^{12}$ Micronuclei has been used as a biomarker for assessment of DNA damage. ${ }^{14}$ When compared with other body sites, mouth provides with a distinct opportunity for defining biomarkers because the mouth permits noninvasive, repetitive examinations in longitudinal studies of tobacco-associated acute and chronic diseases. ${ }^{15}$

There are many studies (more than 200) in which epithelial cells from other site such as nasal mucosa, cervix, bladder, esophagus and bronchi had been used for micronuclei assay. ${ }^{16}$ Biomarkers help to detect high-risk patients. They are divided into three groups: First to define the exposure to carcinogenic agents, the second to show biological effects on the target tissue and the third to give information about the individual susceptibility. ${ }^{17}$ The micronucleus assay in exfoliated buccal cells is a useful and minimally invasive method for monitoring genetic damage in humans. ${ }^{18}$

\section{REFERENCES:}

1. Stich HF, Rosin M.P. Micronuclei in exfoliated human cells as a tool for studies in cancer risk and cancer intervention. Cancer Letters. 1984 Apr; 22 (3): 241-53.

2. Schmid W. The micronucleus test. Mutat Res 1975; 31: 9-15.

3. Kumar V, Rao NN, Nair NS. Micronuclei in oral squamous cell carcinoma: A marker of genotoxic damage. Indian J Dent Res 2000; 11: 101-6.

4. Anneroth G, Batsakis J, Luna M. Review of the literature and a recommended system of malignancy grading in oral squamous cell carcinomas. Scand J Dent Res 1987; 95: 229-49.

5. Tolbert PE, Shy CM, Allen JW. Micronuclei and other nuclear anomalies in buccal smears: A field test in snuff users. Am J Epidemiol 1991; 134: 840-50.

6. Tolbert PE, Shy CM, Allen JW. Micronuclei and other nuclear anomalies in buccal smears: Method development. Mutat Res 1992; 271: 69-77. 
7. Nair U, Obe G, Nair J, Maru GB, Bhide SV, Pieper R, et al. Evaluation of frequency of micronucleated oral mucosal cells as a marker for genotoxic damage in chewers of betel quid with or without tobacco. Mutat Res 1991; 261: 163-8.

8. Casartelli G, Bonatti S, De Ferrari M, Scala M, Mereu P, Marqarino G, et al. Micronucleus frequencies in exfoliated buccal cells in normal mucosa, precancerous lesions and squamous cell carcinoma. Anal Quant Cytol Histol 2000; 22: 486-92.

9. Sun Z, Li N, Zhang Z. The correlation analysis between frequency of micro nucleated cells of exfoliated oral mucosa cells and oral mucosa cells in different grading of oral leukoplakia lesions. Zhonghua Kou Qiang Yi Xue Za Zhi 2000; 35: 439-41.

10. Rickes LN, Alvarengo MC, souza TM, Garcias GL, Martino-Roth MG. Increased micronucleus frequency in exfoliated cells of the buccal mucosa in hairdressers. Genet Mol Res 2010; 9: 19218.

11. Jois HS, Kale AD, Mohan Kumar KP. Micronucleus as Potential Biomarker of Oral Carcinogenesis. Indian J Dent Adv 2010; 2: 197-202.

12. Holland N, Bolognesi C, Kirsch-Volders M, Bonassi S, Zeiger E, Knasmueller S, et al. The microncleus assay in human buccal cells as a tool for biomonitoring DNA damage: The HUMN project perspective on current status and knowledge gaps -.Review. Mutat Res 2008; 659: 93108.

13. Bonassi S, Neri M, Lando C, Ceppi M, Lin YP, Chang WP, et al. Eff ect of smoking habit on the frequency of micronuclei in human lymphocytes: Results from the Human MicroNucleus project. Mutat Res 2003; 543: 155-66.

14. Sivasankari NP, Kaur S, Reddy KS, Vivekanandam S, Rao KR. Micronucleus index: An early diagnosis in oral carcinoma. J Anat Soc India 2008; 57: 8-13.

15. Proia NK, Paszkiewicz GM, Nasca MA, Franke GE, Pauly JL. Smoking and smokeless tobaccoassociated human buccal cell mutations and their association with oral cancer $-\mathrm{A}$ review. Cancer Epidemiol Biomarkers Prev 2006; 15: 1061-77.

16. Nersesyan A, Kundi M, Atefie K, Hermann RS, Knasmuller S. Effect of staining procedures on the results of micronucleus assays with exfoliated oral mucosa cells. Cancer Epidemiol Biomarkers Prev. 2006; 15: 1835-40.

17. Bloching M, Hofmann A, Lautenschläger C, Berghaus A, Grummt T. Exfoliative cytology of normal buccal mucosa to predict the relative risk of cancer in the upper aerodigestive tract using the MN-assay. Oral Oncol 2000; 36: 550-5.

18. Holland N, Bolognesi C, Kirsch-Volders M, Bonassi S, Zeiger E, Knasmueller S, et al. The micronucleus assay in human buccal cells as a tool for biomonitoring DNA damage: The HUMN project perspective on current status and knowledge gaps. Mutat Res 2008; 659: 93-108s.

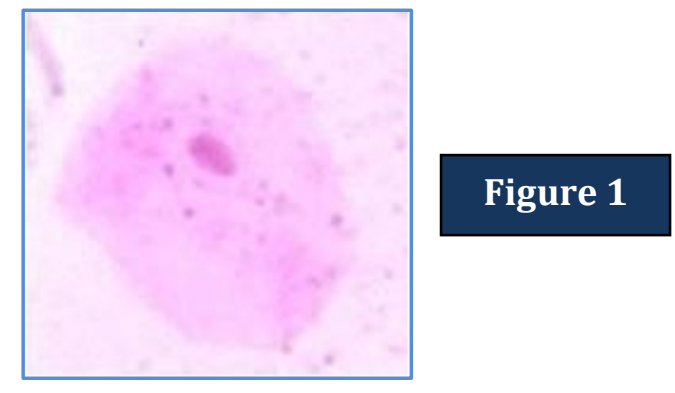




\section{AUTHORS:}

1. Ankit Agarwal

2. Rinky Ahuja

3. Manisha Tijare

4. Sonalika Ghate

5. Anand Tegginamani

6. Sanyog Pathak

\section{PARTICULARS OF CONTRIBUTORS:}

1. Senior Lecturer, Department of Oral Pathology, Hitkarini Dental College \& Hospital, Jabalpur, Madhya Pradesh.

2. Senior Lecturer, Department of Oral Pathology, Peoples Research Centre, Bhopal, Madhya Pradesh.

3. Professor \& HOD, Department of Oral Pathology, Peoples College of Dental Sciences and Research Centre, Bhopal, Madhya Pradesh.

4. Senior Lecturer, Department of Oral Pathology, Hitkarini Dental College \& Hospital, Jabalpur, Madhya Pradesh.
5. Professor, Department of Oral Pathology, Hitkarini Dental College \& Hospital, Jabalpur, Madhya Pradesh.

6. Reader, Department of Surgery, Hitkarini Dental College \& Hospital, Jabalpur, Madhya Pradesh.

\section{NAME ADDRESS EMAIL ID OF THE CORRESPONDING AUTHOR:}

Ankit Agarwal

C/o S. P. Singh,

House No. 175,

Plot 597, Sanjeevni Nagar, Jabalpur-482003,

Madhya Pradesh.

Email: ankitbdsdr@gmail.com

Date of Submission: 08/09/2014.

Date of Peer Review: 09/09/2014.

Date of Acceptance: 10/09/2014.

Date of Publishing: 01/10/2014. 